UDC 378.091.31:378.011.3-051:81'243

DOI: $10.52534 / \mathrm{msu}-$ pp.7(2).2021.18-24

\author{
Halyna V. Prystai ${ }^{*}$ \\ Drohobych Ivan Franko State Pedagogical University \\ 82100, 24 Ivan Franko Str., Drohobych, Ukraine
}

\title{
Methodological Foundations of the Development of Professionally-Oriented Sociocultural Competence of a Foreign Language Teacher Using the Newspaper Material
}

\author{
Article's History: \\ Received: 01.02.2021 \\ Revised: 09.04.2021 \\ Accepted: 22.05.2021
}

\section{Suggested Citation:}

Prystai, H.V. (2021). Methodological foundations of the development of professionally-oriented sociocultural competence of a foreign language teacher using the newspaper material. Scientific Bulletin of Mukachevo State University. Series "Pedagogy and Psychology", 7(2), 18-24.

\begin{abstract}
The paper covers the features of development and improvement of sociocultural knowledge, skills and abilities of future foreign language teachers in the development of their professionally-oriented sociocultural competence. The relevance of the study is determined by the necessity to analyse the methods of using newspaper publications in the process of mastering sociocultural knowledge and forming sociocultural skills of philology students. The purpose of the study is to cover the features of applying the methodology for forming the sociocultural competence of a future English teacher through the use of newspaper material. In the process of study, the method of critical analysis of scientific literature was applied; the method of studying and generalising the experience of teachers; the method of theoretical analysis and synthesis in identifying the linguistic and stylistic features of English-language newspaper texts, in the process of analysing the principles and criteria for selecting newspaper articles, as well as to characterise the types of reading according to the communicative goals and stages of working with the text; the method of systematisation and generalisation in the study of research results. It was identified that the involvement of elements of the language culture of the people whose language is being studied in the content of learning is facilitated by Mass Communication Media, in particular newspapers. It was reasoned that newspaper articles provide the development of foreign language communicative competence, enriching the student's vocabulary, improving his skills and abilities in reading and speaking. It was proved that the tasks compiled based on newspaper material contribute to the creation of an authentic sociocultural space, develop students' ability to analyse patterns of speech behaviour in their native and foreign languages, improve their communicative skills and language competence, deepen background knowledge, and increase motivation to learn. The scientific novelty of the results lies in the detailed description of the requirements for exercises of the sociocultural direction, and their practical significance lies in the possibility of applying the results of the study in teaching a foreign language in the higher educational institutions
\end{abstract}

Keywords: newspaper article, sociocultural knowledge, skills and abilities, philology student, competency-based approach 


\section{INTRODUCTION}

The competency-based approach to learning a foreign language contributes to better results and involvement of the student in the process as a subject of learning [1-3]. This approach involves the use of innovative technologies, training in cooperation, and the use of knowledge from various branches of science. According to the recommendations of the European Commission on the main eight personal competencies necessary for lifelong improvement, cultural (or cross-cultural, sociocultural) competence occupies a key place [4].

Sociocultural competence covers knowledge (ideas, concepts, facts), skills (the ability to apply the acquired knowledge in practice), and attitudes (the interpretation or reaction of a person to certain circumstances, people, or ideas). For example, the necessary sociocultural knowledge when learning a foreign language includes knowledge about the culture, customs, and traditions of the people whose language is being studied, understanding the similarities and differences with the culture of their own people. Sociocultural skills include the skills of independent interpretation and expression of ideas in a foreign language, the ability to realise the abilities for personal and public good. A positive attitude to a foreign language, respect for cultural characteristics, openness to new ideas and a desire to cooperate, to conduct an intercultural dialogue indicates a proper sociocultural awareness of the individual. This competence is being formed and developed due to the different environment in which a person can be situated: family, school, higher educational institution, work, and so on.

As the analysis of scientific literature has shown, sociocultural competence as a component of foreign language competence has been the subject of research by many Ukrainian and foreign scientists. The theoretical foundations, content, and structure of sociocultural competence are covered in the scientific studies by S. Shekhavtsova [5], L. Hitsenko [6], L. Elphiston [7] et al. When the elements of the language culture of the people whose language is being studied are involved in the content of education, the problem of matching of the language environment arises. The importance of using authentic materials as the main source of successful foreign language acquisition is proved by the studies of I. Kolomiychuk [8], I. Zakiryanova [9], M. Bayram [10]. In some studies, attention is focused, in particular, on the effectiveness of mastering the foreignlanguage cultural component through the media and e-learning [11-13]. These studies prove that didactic material taken from original sources performs a double function: it serves as a source of sociocultural information about foreign-speaking countries and acts as a means of developing communicative skills and language competence. In the research of M. Maksimets [14], A. Nipadimka [15], the features of the development of foreign-language speaking skills and abilities in students of linguistic and non-linguistic specialisations are described. Scientists advise overcoming the problem of authenticity of the language environment by using original materials in the classroom: audio texts, video materials, works of art, TV programmes, podcasts, video blogs, movies, etc. Foreign-language newspaper articles stand out from this list because they have a number of advantages: accessibility, relevance of the information provided, information richness, contain country specific and sociocultural value, provide the development of basic language knowledge of students (lexical, grammatical, orthographical), improve reading and speaking skills (when discussing what they read, formulating arguments and expressing their own opinion), expand background knowledge about the modern political, socio-economic and cultural life of the people whose language is being studied. Thus, educators I. Isaeva and N. Sabanska investigated the possibility of using newspaper material for the development of foreign-language communicative and sociocultural competence of future frontier guards [16]; L. Kunitsia, G. Cherednichenko and L. Shapran focused on the methodology of working with periodicals in non-linguistic higher educational institution [17]. However, the methods of organising and composing exercises for the development of sociocultural competence based on reading newspapers and methodological techniques for their use in classes with future foreign language teachers were not the subject of a separate scientific review.

The purpose of the study was to cover the features of applying the methodology for developing the sociocultural competence of a future English teacher through the use of newspaper material. The achievement of a set purpose involves solving the following tasks:

1) to describe the linguistic and stylistic features of newspaper texts and their selection parameters;

2) to clarify the requirements for exercises for the development of sociocultural competence of philology students based on newspaper texts;

3) to specify ways to organise educational newspaper material according to the communicative goals of reading.

\section{METHODOLOGY}

The research methodology is outlined by the tasks and material of the study; therefore, it has a complex nature. In the course of the study, a number of methods of scientific and pedagogical research were used. Among them:

1. Method of critical analysis of Ukrainian and foreign methodological, pedagogical, and linguistic literature on the subject matter. It is applied in the analysis of the advantages of the competency-based approach as one that encourages an individual to self-development throughout life and to improve his sociocultural awareness, skills, and abilities. For this purpose, the recommendations of the European Commission on the main eight competencies of the individual, foreign language curricula for general education institutions and specialised schools with advanced study of foreign languages (grades 10-11), scientific studies that highlight the advantages of a competency-based approach at different levels of education in Ukraine - from primary to professional higher education. In addition, the method of critical analysis helped to determine the place of sociocultural competence in the structure of foreign lan- 
guage communicative competence in the training of a future foreign language teacher in the higher educational institutions. This method is also used to formulate the conclusions of this study.

2. The method of theoretical analysis and synthesis helped to find out the linguistic and stylistic features of newspaper texts as an effective and relevant source of cultural, linguistic, and sociocultural information. The texts of the English-language newspapers The Times, The Guardian, The Washington Post, The Independent, and the Daily Telegraph for 2019-2020 were used as illustrative material. Using this method, the paper provides a detailed description of the principles and criteria for selecting a journalistic text, as well as the topics of sociocultural material for classes with philology students.

3. The method of induction and deduction contributed to a detailed description of the types of reading according to communicative goals, as well as helped to determine the essence and sequence of stages of working with the text.

4. The method of studying and summarising the experience of teachers of Ivan Franko Drohobych State Pedagogical University allowed clarifying the methodology for organising work with the newspaper in a foreign language lesson in the higher educational institution.

5. The classification method made it possible to logically divide reading types into groups based on common characteristics.

6. The method of systematisation and generalisation is used to summarise the results of the study.

\section{RESULTS AND DISCUSSION}

Newspaper style is a special subtype of journalistic style with its own lexical, semantic, and stylistic features, with characteristic expressive, informative, and manipulative functions. An analysis of the texts of broadsheet English-language newspapers The Times, The Guardian, The Washington Post, The Independent, and The Daily Telegraph for 20192020 has shown that English newspaper style is a system of interrelated lexical, phraseological, and grammatical means that form a separate linguistic unit - text. It was found that information is provided through short news, reports, informational articles, as well as articles on various topics. A functional approach to the analysis of newspaper material has confirmed that the communicative aspect of speech is used to communicate or transmit information, in a journalistic article - an impressive aspect, in a report expressive. The language of the newspaper style is dynamic, it is characterised by a combination of norms of oral and written speech.

First of all, attention was paid to the linguistic and stylistic characteristics of the title text. It was established that the headline of an English-language newspaper can report a fact: Google builds giant cable from Cornwall to New York (The Times), First Trump-Biden debate shifts to Cleveland as Notre Dame backs out (The Washington Post); to interest or attract the reader's attention with meaningful content for an intriguing or manipulative purpose: Meet the doctor who says we have been showering wrong (The Guardian),
Junk food isn't the only enemy, it's products pretending to be healthy (The Independent). It was found that when writing headings, articles and linking verbs are often omitted: Second wave has started in Europe (The Times); Almost 3 billion animals affected by Australian bushfires (The Guardian); End of UK-Spain air bridge as much about politics as hard data (The Guardian); US sends more planes to keep watch in China (The Times); nominative sentences are used: Politics at the point of a gun; The extraordinary campaign to unseat Belarusian 'dictator'; 10 ways to improve your health and fitness (The Times); non-personal verb forms are used: Extending furlough scheme would save $1.2 \mathrm{~m}$ jobs (The Independent); Sending animals to war zones (The Guardian); interrogative sentences are used: Is this the second wave? (The Times); Who do you think Joe Biden should choose for VP? (The Washington Post); wordplay, or pun is used: Police were found drunk in the street (this can be interpreted in two ways: a police officer was found drunk or the police found a drunk on the street); a pile of nouns in the title is used: Prime Minister's traffic headache or Teenage pregnancy increase; present simple or infinitive instead of perfect or continuous tense is used: Lebanon justice minister resigns after port blast (instead of "has resigned") or President to visit Hiroshima (instead of "is going to visit").

To intrigue the reader, most articles contain a question that the author gives a reasoned answer to: Will the fact masks are now obligatory in shops in England finally - please God - mark the end of the mask culture wars? Will this spark a political and public commitment to sane and effective public health policies? Well, yes and no. On the one hand, it's a relief that the government has finally listened to what the World Health Organization has been saying in increasingly desperate tones since early spring. On the other, complementary goggles seem to be required to make your way through this murky mire of regulation, social codes and libertarian posturing (The Guardian). It was found that the lexical content of articles is emotional, mostly covering exciting or negative events: British academic moved to notorious desert prison in Iran (The Times), 'No masks allowed' sign removed from seaside takeaway (The Independent).

In newspaper articles, the presence of socio-political vocabulary is recorded: The Tories can't put off a new property tax for ever (The Times); Antics of Trump ambassadors highlight crisis in US diplomacy (The Guardian); US Republicans pandemic recovery plan could cut unemployment payments (The Independent); terminology, in particular medical terminology: three-parent embryos, oocyte [egg] nucleus transfer, super-spreader. In addition, the analysed printed texts often include: idioms: He injected jazz, a few bad apples spoil the bunch, beyond the pale; neologisms: gymgerly, Trumpism, glocalization (global + local), abbreviations BAME (black, Asian and minority ethnic), BLM (Black Lives Matter) FSA (Food Standards Agency), IPCC (Intergovernmental Panel on Climate Change), WWF (World Wide Fund for Nature); cliches: vital issue, key speakers, core issues, pillar of society, blame game, banana republics, escalation of war, officials say; frequent use of proper names, 
toponyms, names of organisations, dates, and numerals. In addition, newspaper texts are rich in syntactic means, for example, oppositeness, parallelisms, repetitions: Good teachers got rewarded while bad teachers got the boot (The Times), Populists on both left and right claim to be fighting for 'the people' (The Independent).

As is evident, the English newspaper style is complex and multifaceted. It is the main means of reflecting changes in society by means of language, and therefore this style is rich in linguistic innovations, heterogeneity of syntactic and stylistic techniques. Newspaper style is an inexhaustible source of linguistic and foreign studies material, an intermediary in the development of a general picture of the world and, of course, a means to properly master English language. To effectively determine the direction and features of the methodology for applying English-language newspaper texts in the classes in higher educational institutions, it is necessary to clarify the principles and criteria for their selection.

As the analysis of scientific and methodological literature on the topic has shown, in the process of analysing and organising newspaper material, methodologists $[8 ; 16 ; 17]$ advise adhering to the following principles:

1) to use authentic material, which was created to achieve a specific social purpose (to attract attention, arouse admiration or indignation). Such newspaper excerpts help to understand the current circumstances, the political, economic, or cultural picture of an individual language community;

2) newspaper texts must carry a certain amount of sociocultural subtext in order to expand the ideological potential of philology students;

3 ) it is advisable to follow a thematic integrity, namely, to select materials within the topics provided for in the work programme of the educational discipline;

4) in order to encourage increased speech activity, the principle of communicative skills provides understanding of speech material, development of logical presentation of thoughts, forms aesthetic taste.

The principles outlined above have an impact on the nature of exercises, methods and techniques of teaching using newspaper texts. They determine the use of certain criteria - selection rules based on certain qualitative and quantitative characteristics, namely: thematic, informative content of the text, suitability of the teaching content, prospects for studying, readability, country specific and sociocultural value. Thus, the teacher should organise the lexical material in accordance with the subject content (namely, take into account a certain conversational topic being studied in order to ensure complexity and cyclicity), take into account the informative content, logic, and/or emotionality of the abstract/article. Therefore, to ensure the formation and development of sociocultural competence, it is worth using such sociocultural newspaper material:

- review of sports news; interviews with athletes, chefs; advertising of health centres, sports complexes, medical products; announcements about mass sports events; recipes for cooking national cuisine;

- political reviews, materials on socio-political topics; interviews with famous people, on-the-spot news reporting; announcements about performances, concerts, festivals; invitations to an art gallery and museum, reviews of films, programmes for sports events, guided tours, and entertainment during the summer holidays; advertising of hotels, hostels, hairdressers; vouchers (invitation discounts) to restaurants, cafes, bars;

- articles about the education system and school problems; advertising of training centres, foreign language courses; ads for employment.

As the study and generalisation of the positive work experience of teachers of Ivan Franko Drohobych State Pedagogical University has shown, it is advisable to choose the following forms of working with a newspaper on a foreign language lesson:

- front-collective (all students take part in solving tasks; the teacher directs their cognitive activity);

- group (solving tasks in small groups of 3-5 students with different academic performance);

- individual (independent performance of a separate task by a student offline or online).

It was established that the communicative goals of reading may differ, so the types of reading and their purpose are also different. Scientists distinguish three types of educational reading: skimming, scanning (selective), reading for detail (complete) [18]. For example, the purpose of skim reading is to understand $75 \%$ of basic information at a reading speed of about $180-190$ words per minute. To develop introductory reading skills, the teacher should use large texts that are not difficult to understand. To achieve a proper result, the teacher suggests identifying the topic or main idea of the message; guessing the content of the message by reading the title; focusing on the main facts or problems; agreeing or challenging the proposed statements; choosing the image that best illustrates the above; briefly transmitting the content of the passage; expressing your opinion on the problem mentioned in the text, etc. Here are the examples of the tasks for developing skills in understanding basic information:

- Read the headline and guess what the article is about.

- Read the article quickly to find out what it is about. Choose the best headline/summary for the text.

- Find the following words in the article, and then write a definition for them in English.

- Correct the false statements.

- Choose from a number of pictures those that illustrate the article.

- Choose one of the statements below that you think corresponds the article the best.

- Briefly convey the main content of the article.

- What do you think of the problem mentioned in the article? Scanning aims to quickly find specific information by viewing a range of ads, programmes, recipes, and so on. The degree of understanding of the text is $40-50 \%$, and the reading speed is $400-500$ words per minute. In the tasks for the development of skills in finding specific information, it is suggested combining words into phrases, finding convincing arguments for or against a certain behaviour/ action/idea, summarising in one sentence what is said 
in each of the paragraphs of the article, making a plan of the article and retelling it, using this plan, expressing an opinion about what a student has read:

- Read the text below. Match choices A-F to 1-6.

- Which of the advertisements is about...?

- Which of the arguments below are for and which are against (social distancing)?

- Read paragraphs 1-5 and summarize each one in a single sentence.

- Make up a plan on the article.

- Tell your group mates about your text using the notes.

- Retell the article expressing your opinion on the problem.

Reading for detail, or complete reading is a deep, detailed understanding of a text followed by one's own interpretation. It helps to develop the ability to independently cope with language or content difficulties. Reading speed of 50-60 words per minute with the full understanding of the text. Author columns and articles of an informative nature can serve as newspaper material. Examples of communication tasks: write out the most significant information from the abstract, answer the questions, translate the article into Ukrainian, comment on the problems highlighted, retell the information to others, compare the information with one's experience. Thoughtful reading tasks might look as follows:

1. Copy out the most important information from the text.

2. Answer the questions on the text.

3. Make the written translation of the article in Ukrainian.

4. Read the text again. Discuss which of the ideas do you think is the best/worst?

Regardless of the type of reading, work with the newspaper text is being carried out according to the following stages [19]:

1. At the preparatory stage, the teacher analyses the newspaper material in accordance with the principles and selection criteria.

2. During of pre-text work in the classroom, the teacher:

- activates background sociocultural knowledge (about national culture, rules of behaviour, mentality, history), as well as knowledge from students' own experience. To create an appropriate linguistic/situational atmosphere, a number of pedagogical methods are used, including a "memory card": students select words or phrases associated with the keyword located in the centre of the blackboard. The "memory card" develops critical thinking, teaches to distinguish the main point from the secondary, as well as to think independently; the "brainstorming" method helps remembering information related to the topic of discussion; the discussion method helps formulating and expressing one's own arguments in support of one of the two contradictory ideas;

- helps to overcome lexical and grammatical difficulties before reading the text. Unfamiliar words are interpreted (if possible, in a non-complicated way), proper or geographical names are worked out, and the political/social realities of the country whose language is being studied are explained. When working with overcoming difficulties, methodologists recommend selecting texts with a certain amount of new vocabulary (approximately 6\%) to promote the development of speech guesswork;

- formulate a pre-text communication task in the form of a question/several questions. The purpose is to focus on finding and perceiving the necessary sociocultural information. Students search for answers to questions by reading the text. Examples of pre-text tasks: divide the article into three semantic parts (introduction, main, and final part); arrange the sentences in a logical sequence; select keywords; formulate the topic of the article; guess from the context what is the meaning of these words in this passage.

3. Actually reading and understanding the text. The amount of time varies depending on the complexity of the text.

4. Post-text stage. Its purpose is to control reading comprehension and develop the ability to formulate value judgments. The possible tasks include: answer questions; describe the drawing to the text; express your opinion on the statement; name the facts from this text that were unexpected/new/useful for you and why? In addition, this includes such cognitive-receptive tasks as: in the first paragraph, find a sentence that contains main information; name the sentence/paragraph that talks about; find facts that confirm/deny; name the issues that were raised in the text. Full understanding of the text content and training of vocabulary use occurs at the level of a phrase/collocation. Performing exercises that include selection, regrouping, analysis or synthesis, and searching for arguments help students to develop the ability to analyse the language and stylistic features of a newspaper text.

5. Stage of communication practice. Its goal is the independent application of linguistic material in all types of speech activity, both receptive (reading and listening) and productive (speaking and writing). An effective method at this stage is comparative analysis, when after reading a text about the realities of someone else's culture, students in groups or individually write a similar text, comparing common and distinctive features with the phenomena of their native culture. Another method - the method of modelling educational communicative situations is based on role-playing games, creating projects, portfolios, and so on. For example, to discuss the issues covered in the article, the teacher can suggest an interactive role-playing game "press-conference". One group of students formulates questions about the problems described in the article, while others cover them in their short speeches. This form of work develops the skills to correctly select words and phrases according to the situation, communicate, applying the acquired knowledge. In order to creatively apply the previously worked-out information in a new situation, the teacher asks discussion questions, motivating students to solve a certain communicative problem and causing a certain emotional reaction.

6. The final stage. Its purpose is to prepare for the retelling of what students have read by drawing up a plan for their own story or writing out reference words, phrases, and collocations from the text. The next step is to retell the text and express their own point of view regarding the events, facts, and problems described in the newspaper material. 


\section{CONCLUSIONS}

Thus, newspapers as a source of authentic sociocultural material contribute to the development of professionally-oriented sociocultural competence of a foreign language teacher. Firstly, they help to solidify vocabulary or work out grammar in accordance with the purpose of the lesson, improving all speech competencies. Secondly, they update the teacher's background knowledge and experience in order to expand his cultural and/or national awareness of the country whose language he is teaching. It has been proved that with the systematic use of newspapers in foreign language classes, sociocultural knowledge, skills and abilities, and foreign language communicative competence in general are formed and developed.

To cover the features of applying the methodology for developing the sociocultural competence of a future English teacher by using newspaper material, the study describes the linguistic and stylistic features of newspaper texts. It has been found that the newspaper style of Englishlanguage newspapers has its own lexical, semantic, and stylistic features. The study describes the parameters of newspaper material selection in accordance with the purposes of a foreign language lesson in the higher educational institution. Among them are criteria for thematic content, informative content of the text, suitability of the teaching content, prospects for studying, readability, country specific studies, and sociocultural value. The requirements for exercises based on newspaper texts are specified in accordance with the communicative goals of reading, such as developing skimming, scanning, and detail reading skills. Accordingly, the speed of reading and the degree of reading comprehension were clarified. The requirements for the stages (preparatory, pre-text, reading stage, posttext, communication practice, and final stage) of working with sociocultural material selected from the newspaper are detailed. The prospects for further research are the composition of a system of exercises aimed at the formation and development of sociocultural competence of students of philological specialisations of pedagogical universities.

\section{REFERENCES}

[1] Curriculum in foreign languages for secondary and specialized schools with in-depth study of foreign languages 10-11 forms. (2017). Retrieved from https://osvita.ua/doc/files/news/589/58921/inozemni-movi-10-11-19_09_2017.pdf.

[2] Redko, V.H. (2017). Competence-based teaching of foreign languages at primary school: Lingual and didactic aspects. Problems of a Modern Textbook, 18, 178-191.

[3] Malykhin, O.V. (2016). Competence approach in teaching foreign language of philology students. Young Scientist, 12.1(40), 462-465.

[4] Key competences for lifelong learning. (2019). Retrieved from https://op.europa.eu/en/publication-detail/-/ publication/297a33c8-a1f3-11e9-9d01-01aa75ed71a1/language-en\#.

[5] Shekhavtsova, S.O. (2020). Linguacultural competence of future specialists as a key competence in current educational environment. Bulletin of Luhansk Taras Shevchenko National University, 2(333)/2, 72-79.

[6] Khitsenko, L.I. (2016). Criteria, indicators and levels of development of socio-cultural competence. Collection of Research Papers "Pedagogical Science", 74(1), 145-150.

[7] Elphinstone, L. (2018). Cultural competence for teachers and students. In K. Keith (Ed.), Culture across the curriculum (pp. 46-68). Cambridge: Cambridge University Press.

[8] Kolomiychuk, I.M. (2017). Authentic materials as the effective means of providing the socio-cultural direction in foreign language teaching. Bulletin of Alfred Nobel University. Series "Pedagogy and psychology", 1(13), 102-105.

[9] Zakiryanova, I.A. (2016). Forming sociocultural competence of future teachers of the foreign languages (English) in the process of professional training (Doctoral thesis, Institute of Higher Education of the Academy of Pedagogical Sciences of Ukraine, Kyiv, Ukraine).

[10] Byram, M., \& Wagner, M. (2018). Making a difference: Language teaching for intercultural and international dialogue. Foreign Language Annals, 51, 140-151.

[11] Wu, P.H., \& Marek, M.W. (2018). Developing intercultural competence via social media engagement in a language learning framework. Journal of Intercultural Communication, 46. Retrieved from http://immi.se/intercultural/nr46/wu.html.

[12] Nguyen, T.T.H., \& Nguyen, T.M. (2019). Information technology and teaching culture: Application in classroom. In V. Uskov, R. Howlett, \& L. Jain (Eds), Smart Education and E-Learning 2019 (pp. 343-355). Singapore: Springer.

[13] Prystai, H.V. (2019). Technology of blended learning in the formation of professional foreign language competence of the teacher. Young Scientist, 4.2(68.2), 186-188.

[14] Maksymets, M. (2006). Formation of socio-cultural competence in the process of learning English. Visnyk of the Lviv University. Series Pedagogics, 21, 211-218.

[15] Nypadymka, A.S., \& Sarnovska, N.I. (2016). The role of authentic texts in teaching foreign languages to future foreign relations specialists. Young Scientist, 4.1(31.1), 84-87.

[16] Cherednichenko, H.A., Shapran, L.Yu., \& Kunitsa, L.I. (2011). Methods of work with newspapers and magazines in the process of learning the foreign language at non-linguistic tertiary educational institutions. Teaching Languages at Higher Institutions, 18, 283-291. 
[17] Isaeva, I.F., \& Sabanska, N.M. (2015). Use of newspapers at foreign language lessons as a means of professional foreign communicative and sociocultural competence forming of future border guard officers. Collection of Scientific Studies of the National Academy of the State Border Guard Service of Ukraine. Series: Pedagogical Sciences, 2, $107-120$.

[18] Plaskina, M.V. (2014). Analysis of modern theories of teaching reading in a foreign language. In Problems and prospects for the development of education: Materials of the scientific conference with international participation (pp. 133-136). Perm: Mercury.

[19] Boretska, H.E. (2012). Methods of forming foreign language competence in reading. Foreign Languages, 3, 18-27.

\section{Галина Василівна Пристай}

Дрогобицький державний педагогічний університет імені Івана Франка 82100, вул. Івана Франка, 24, м. Дрогобич, Україна

\section{Методичні основи формування професійно-орієнтованої соціокультурної компетентності вчителя іноземної мови шляхом використання газетного матеріалу}

Анотація. У статті розглянуто особливості розвитку та вдосконалення соціокультурних знань, умінь i навичок майбутніх учителів іноземної мови за формування їхньї професійно-орієнтованої соціокультурної компетентності. Актуальність дослідження детермінована необхідністю аналізу методів використання газетних публікацій у процесі засвоєння соціокультурних знань та формування соціокультурних умінь і навичок студентів-філологів. Мета статті - розкрити особливості застосування методики формування соціокультурної компетентності майбутнього вчителя англійської мови шляхом використання газетного матеріалу. У процесі роботи застосовано метод критичного аналізу наукової літератури; метод вивчення й узагальнення досвіду викладачів; метод теоретичного аналізу й синтезу в з’ясуванні лінгвостилістичних особливостей англомовних газетних текстів, у процесі аналізу принципів і критеріїв відбору газетних статей, а також для характеристики видів читання згідно 3 комунікативними цілями та етапами роботи 3 текстом; метод систематизації й узагальнення у вивченні результатів дослідження. 3'ясовано, що залученню в зміст навчання елементів мовної культури народу, мова якого вивчається, сприяють засоби масової комунікації, зокрема газети. Обгрунтовано, що газетні статті забезпечуюють розвиток іншомовної комунікативної компетентності, збагачуючи словниковий запас студента, удосконалюючи його вміння, навички й здібності в читанні та говорінні. Доведено, що укладені на основі газетного матеріалу завдання сприяють створенню автентичного соціокультурного простору, розвивають у студентів уміння аналізувати зразки мовної поведінки в рідній та іноземній мовах, покращують їхні комунікативні навички та мовну компетентність, поглиблюють фонові знання та підвищують мотивацію до навчання. Наукова новизна результатів полягає в детальній характеристиці вимог щодо вправ соціокультурного спрямування, а їхня практична значущість - у можливості застосування результатів дослідження при викладанні іноземної мови у $3 \mathrm{BO}$

Ключові слова: газетна стаття, соціокультурні знання, вміння й навички, студент-філолог, компетентнісний підхід 